\title{
En prevención escolar un enfoque basado en la evidencia significa una lucha diaria: un caso práctico sobre la experiencia en la República Checa con los estándares nacionales de calidad y el sistema nacional de certificación
}

\section{An evidence-based approach in school prevention means an everyday fight: a case study of the Czech Republic's experience with national quality standards and a national certification system}

| MiCHAL MiOVSKY

\section{Resumen}

La República Checa ha conseguido por fin, tras un largo periodo de 15 años, el desarrollo de un sistema nacional de prevención en las escuelas. La reflexión sobre este desarrollo puede constituir un interesante caso práctico que demuestre las dificultades generales que participan en la creación de una política general de prevención y de implementación de los principios de un enfoque basado en la evidencia. A través de su contexto histórico se presentan los resultados actualizados de los últimos proyectos como 'documentos clave' (estándares de calidad, manual, diccionario explicativo, ejemplos de buenas prácticas, etc.) y un sistema nacional de evaluación de la calidad denominado procedimiento de certificación, que tiene un impacto práctico en el sistema de subvenciones del Ministerio de Educación de la República Checa. También se utiliza este contexto para mostrar cómo ciertas redes europeas (EUSPR, IREFREA, etc.) pueden ser de gran utilidad para generalizar esta idea en toda Europa. Todos los ejemplos de actividades presentados, tanto a nivel nacional como internacional, parecen prometedores y apoyan una tendencia cada vez más indiscutible de utilizar la evidencia científica en la práctica real, lo que a su vez contribuye en que todo el campo resulte más atractivo tanto para los estudiantes como para los investigadores jóvenes.
Department of Addictology, 1st Faculty of Medicine,

Charles University and General University Hospital, Prague

Enviar correspondencia a

Michal Miovsky

mmiovsky@adiktologie.c
Palabras claves: prevención escolar, intervenciones preventivas, calidad, evidencia científica, política preventiva.

\section{Abstract}

The Czech Republic has reached the end of a 15-year-long period of the development of a nationwide preventive system in schools. Reflection on this development can offer an interesting case study that demonstrates the general difficulties involved in creating a national prevention policy and implementing the principles of an evidence-based approach. Through its historical context the up-to-date outputs of the latest projects are presented as "key documents" (quality standards, textbook, explanatory dictionary, examples of good practice etc.) and a national system of assessment of quality called a certification procedure, which has a practical impact on the grant system of the Ministry of Education of the Czech Republic. This context is also used to show how certain European networks (EUSPR, IREFREA, etc.) can be very helpful in generalizing this idea across Europe. All the examples of activities on the national or international level seem to be promising and supportive of the increasingly noticeable trend of using research evidence in real practice and making the whole field more attractive for students and young researchers.

Key words: school prevention, preventive interventions, quality, evidencebased, preventive policy. 


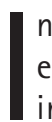
December 2012 my colleagues and I finally reached the end of quite an important period in the latest developments in school prevention in the Czech Republic. It was a sensitive matter for me personally and it made me reflect on what has happened during the last 15 years in our country, and not only from a local perspective. I am sure this reflection has many consequences for the international context and can be an interesting example and possibly something like an exercise in drug policy, or, more specifically, in school prevention. It was 15 years of beliefs and wishes and a series of mistakes and slightly naive expectations. On the other hand, it was a period of hard work and testing our school system and our own abilities as researchers and clinicians.

During the second half of the '90s we commenced discussion about a system of school prevention and we were in communication with many institutions and international bodies. The core problem lay in the integrity of our national concept of prevention and the irrational expectation that governmental bodies have the potential to create the concept and implement the basic principles of an evidence-based approach. It was our first mistake and our real "starting line" was the Phare Twinning Project 2000, which we conducted together with Austria in 1999-2001. Usually, I do not believe that it is possible to achieve a significant improvement through one separate project. In fact, we did not achieve any important positive improvement through this project either but used it to define where we had problems and weaknesses in our system and what it was necessary to change. Last but not least was a "by-product" of the project: real capacity building. When we gave the results to our Government through our Ministry of Education I was highly sceptical. I could not believe that it would be possible to create and develop all the things that were in the list of our top priorities. And the first few years after the project did indeed proceed according to this scenario. There was zero interest from the decision makers and zero support for planning activities. The situation was in contrast with our findings: a mass of terminology, no quality standards or control system, misuse of the grant system, an imbalance in terms of access to the grant system for NGOs and governmental institutions, a poor system for monitoring preventive work, a poor national strategy, a lack of examples of good practice etc. A normal situation. But during this time something matured. Till this day I do not know what exactly it was or is. Some of my colleagues from NGOs managed to keep their motivation and during 2003 and 2004 we created a second version of the quality standards for drug prevention in schools. After a couple of months we gained acceptance from the Ministry of Education and in 2005 the standards were published as an official norm for our schools. The group members were excited and during the following years we created a quality control system for providers and linked the quality standards with the grant system of the Ministry of Education. It means in practice that without a certificate of quality it was not possible to apply to the Ministry for money for school prevention. It does not matter that our Ministry's sponsorship represents less than 20\% of the national budget for school prevention and it does not matter that this step had a more significant impact on NGOs than on governmental institutions. It was up and running and we were excited again despite the fact that it produced a lot of troubles, conflicts, and imbalance. But the system was under pressure. It was probably an important reason why we decided to conduct the most ambitious project in our history.

\section{National quality standards and system of quality certification}

Since the beginning (2005) we have suffered many attacks on this quality control system, with massive criticism, of course, not from regular providers and leaders in the professional field but from many different lobby groups (prevention with government support is sometimes, and in some specific cases, relatively good business, of course) and providers who were "on the margins". This means providers such as golf clubs, football clubs, the Scientologists etc. Sometimes it was a matter of a sufficiently patient approach to working with policy makers, sometimes about working more with the media and providing more information and making research data more available. We were more or less successful and since 2006 the system has covered not only general national quality standards (MSMT, 2005, 2008) but also a sophisticated certification system (Martanova, 2006). We created a system for the assessment of the professional competence of the providers of schoolbased prevention programmes that was focused on formal acknowledgement of the programme's compliance with the quality and comprehensiveness criteria that had been determined. This procedure of assessment has exact norms and definitions and a scoring system with rules for reviewers (Pavlas-Martanova, 2012a, 2012b). The Standards in their final version (Pavlas-Martanova et al., 2012) define the basic terms, target groups of prevention programmes, and efficiency principles. In the first revision of the Standards from 2005 (MSMT, 2005) we stressed the need for closer contact with the reality of the programme, narrowed the Standards and removed any duplication, made the explanation and evaluation more straightforward, and addressed newly encountered situations and amended legislation. In the last revision from 2012 (Pavlas-Martanova et al., 2012) we shifted to more universal application of the standards to all types of risk behaviour.

The core of the conflict was not the existence or content of the national quality standards. The core was the relationship with the financial programme and support provided by the Ministry of Education. Without a certificate of quality it was not possible to apply for money from this main financial programme. The system has many disadvantages and weaknesses. On the other hand, it is a symbol. Since 2005 we have had an explicit definition of what is meant by quality and what we assess and since 2006 we have also had a definition of how. Since this time we have had periods with this unique system and periods when this system has been interrupted by different political decisions. Incidentally, at the present we are still going through a period of this type of interruption as a result of the activities of the former Minister of Education. Nevertheless, there has been considerable change. The directors of schools are better and better oriented. Our preventive workers have all the basic materials available and they use them - the system lives independently and that is an important finding indeed. 


\section{Key documents make a system}

I attempted many times to solve the crucial question of how to manage the prevention system on a nationwide level more professionally and how to link it with evidence-based principles, not only in promotional activities and empty proclamations, but in reality, and probably was not efficient at finding a solution in former times. Our experience was really simple in the end. We lacked a set of documents that we can call "key documents". We define these documents with scientific integrity as a basic terminological, theoretical, practical, and technical framework for school prevention. A national vision needs a uniform framework with clear terminology and definitions. Therefore, in 2009 we applied for and received an EU project funded for the creation of a national system for prevention, from educational standards to examples of good practice. ${ }^{1}$

We started with two core publications: a basic theoretical textbook and a Czech-language explanatory dictionary of terminology (see also Gabrhelik \& Miovsky, 2012). We summarised the basic knowledge in the field of preventive science in both basic monographs, including creating the explanatory dictionary with 28 terms. In the second round it was important to define the basic knowledge, skills, and competencies for preventive professionals. In other words, we tried to define the basic requirements for preventive workers in our country and for this purpose we used the EU system/concept for learning outcomes, which is practical and gives enough space for creativity. Our model is based on this simple principle (Charvat, Jurystova \& Miovský, 2012) and gives the opportunity to discuss core competences for preventive workers independently of their original education (pedagogy, psychology, public health, mental health etc.). The set of documents that dealt with quality standards and the certification procedure was already mentioned above. The last group of documents dealt with practical aspects of everyday preventive work. We formulated a general structure for preventive activities for so-called basic schools (attended by 6-15-year-olds) in the Czech Republic. We call it the Minimum Preventive Programme or a general basic framework for preventive activities in the context of elementary schools (Miovsky, Skacelova, Cablova, Vesela, \& Zapletalova, 2012). The last, but not least important, document has an extraordinary position - examples of good practice (Siruckova, Skacelova, \& Miovsky, 2012). It was very important to have enough real and practical examples and enough evidence of real professional preventive activities in our country (see also Nevoralova, Pavlovska, \& Stastna, 2012). It was also an important symbol. It was no problem to translate many interesting examples and practical tools and preventive methods published in international journals or by prestigious publishing houses. But this has a different value and it has a different practical impact on the mind and on our reflection on what we have and what we have achieved. The decision to collect practical examples directly from the field followed a simple expectation - it has a

\footnotetext{
1 For more information see the special issue of our journal Adiktologie (the full text in PDF format is also provided in English) on our website: http://www. adiktologie.cz/cz/articles/detail/598/4024/Adiktologie-2012-3.
}

greater motivational potential and impact on professionals in the field because of its symbolic background.

It was not easy to create all of these documents in three years and with a team of more than 70 people (in part-time work), but it was a direct way and the ongoing, and genuinely difficult, implementation of these documents is enough evidence for me that it has value. That investment of 15 years' work makes sense today.

\section{The path is not always clear and many countries have many experiences but the most important thing is rules and principles}

The reason why I have briefly reflected on this Czech story is my visits to the last two annual conferences of the EUSPR (the European Society for Prevention Research). ${ }^{2}$ The 2nd International Conference of the EUSPR, "Synergy in prevention and health promotion: individual, community, and environmental approaches", was held in Lisbon in December 2011 and the 3rd International Conference of the EUSPR, "Common risk and protective factors, and the prevention of multiple risk behaviours", in Krakow in December 2012. Both conferences were exciting from the perspective of openness - openness in discussions and comments and high quality in terms of critical perspective. It was a like a breath of fresh air for our joint European discussion and research into prevention and was an excellent opportunity for testing our wider society. Of course, without activities that came before, such as the IREFREA Network (founded in 1988) (see www.irefrea.org) it is hard to imagine such a rapid process of development and such wonderful feedback and support. Something has matured since this time, both in our wider professional society and our institutional context. More could be said about politically-oriented decisions, even now, (among others, in some financial programmes) and the current shift is a positive signal. For preventive research we might use a paraphrase of the instructions from the London Underground: "Mind the gap between science and decision making." I believe that everybody knows these problems in the national context and they are by no means rare on the international level either. I remember the meeting of the Pompidou Group in Prague in April 2010, where some delegates presented "very effective" campaigns provided in some countries (and, of course, supported by incredible budgets). After asking for evidence and the results of the evaluation of these, we received the answer that "It's good, high-quality, and effective because they think it is and they believe..." It is good that we have a professional body and a platform for open discussions, where there is space and a supportive atmosphere for the maturing and cultivation of our points of view and our opinions and arguments and where we can share evidence and get critical feedback and assessment. It is a wonderful opportunity for students and young researchers and increases the chances of creating different communication platforms and working groups with a higher chance and better potential for creating international groups and teams

2 For more info see the website: http://www.euspr.org 
for new research and development projects. Collaboration between bodies on the international level, such as the EUSPR or IREFREA Network, and institutions on the national level, such as universities, NGOs etc., is crucial. It poses a new challenge for different universities in Europe and our MA and PhD students. I see a parallel process with ISAJE (the International Association of Addiction Journal Editors), where, two years ago, we started a discussion about more intensive collaboration between this professional international body and European universities. This year we are testing its first product - a summer school ${ }^{3}$ for MA and PhD students that will train them in publishing skills. These activities make our field more attractive for more students and researchers and can improve the situation in preventive science and practice.

I think that all of these examples are good evidence of the improvement of the current situation, not only in school prevention but prevention generally. The EDDRA system, ${ }_{1}^{4}$ which was created and developed by EMCDDA, has been in existence for a couple of years. It is our joint catalogue of examples of good practice that we can share and from which we can gain inspiration. It is good to know that our troubles are similar, that all of us have to deal with similar difficult situations in our countries, and that we should maintain our faith against populist voices, which are usually quite loud. All the examples that I used from the Czech Republic were born as the result of a long series of frustrating situations and hard work. We found that our internal professional discussion is only one part of the problem. The second part is the media, politicians, teachers, parents and wider public etc. So many target groups for negotiation and discussion for such a small group of professionals! As mentioned above, inspiration and sharing our experiences are among the biggest findings for me personally. There are many useful and creative examples on the national level, e.g. the platform created and developed in Spain under the aegis of an initiative of the leading national professional association, called Socidrogalcohol. ${ }^{5}$ It is important for us to stress here how knowing about national or European projects can help us in developing our own strategies. For instance, a couple of years ago (and the history of our Czech professional journal Adiktologie is not a long one) we were confronted by a strange situation in our editorial board. We received two review papers about preventive nightlife interventions in clubs and at open-air festivals and harm reduction programmes. Both these papers had very positive results from double peerreview assessment and the reviewers stressed not only their quality but also the fact that this was the first time we had had papers in our journal about such a sensitive and important

3 For more information see ISAJE Newsletter December 2012, page 27. Available to download: http://www.parint.org/isajewebsite/ISAJEnewsletterDecember2012.pdf

4 Exchange on Drug Demand Reduction Action (EDDRA): For more information see the website: http://www.emcdda.europa.eu/html.cfm/index52006EN. html?by $=262 \&$ value $=825$

5 For more information see the website www.prevencionbasadaenlaevidencia. net This national platform conducts an on-going mapping of the situation concerning prevention in Spain, gathering the leading people in prevention in this country, creating a catalogue of the main preventive programmes after they had been evaluated on their quality according to standards of excellence, and creating a database of relevant documents for the prevention professionals. area of drug use and professional help and work. And in this situation one of my highly experienced and influential colleagues on the board expressed the attitude that this type of topic and paper is not appropriate for publication and that he was strictly against it. We published both papers, of course - with all the consequences what followed. This was certainly possible because other European groups have been investigating this subject for several years (Calafat, 2010; Calafat, Duch, Juan, \& Leckenby, 2012). I use this example to help to create a better understanding of how important it is to have an opportunity for comparison and inspiration and also to have a chance to have the courage to take some decisions and stress important things and follow an approach that is based on evidence, not on paper and political strategies but our everyday work in our services, journals, and research. I want to thank my colleagues from the Adiciones Journal for the opportunity to express this idea and I hope that the collaboration between our journals on a platform such as ISAJE or between our teams and institutions on a platform such as EU-SPR, or exchanging our experiences on a platform such as the EDDRA system means a future and maybe a slightly optimistic and promising everyday faith against stereotypes, magical thinking, or simplistic populist decisions and opinions.

\section{Acknowledgements}

This work has received grant support from the Institutional programme No. PRVOUK-P03/LF1/9.

\section{References}

Calafat, A. (2010). Life style and drugs. Strasbourg: Council of Europe.

Calafat, A., Duch, M., Juan, M., \& Leckenby, N. (2012). Health and Safety European Standards for nightlife venues. Adicciones, 24, 355-364

Gabrhelik, R., \& Miovsky, M. (2012). Basic texts for the further development of prevention created as part of the VYNSPI Project: Textbook, Dictionary, and Examples of Good Practice [Zakladní texty pro dalsi rozvoj prevence vznikle v projektu VYNSPI: ucebnice, slovnik, priklady dobre praxe]. Adiktologie, 12, 232-243.

Charvat, M., Jurystova, L., \& Miovsky, M. (2012). Four-level model of qualifications for the practitioners of the primary prevention of risk behaviour in the school system [Ctyrurovnovy model kvalifikacnich stupnu pro pracovniky v primárni prevenci rizikového chovani ve skolstvi]. Adiktologie, 12, 190-211.

Martanova, V. (2006). Certification of the Programmes of the Primary Prevention of Substance Use. [Certifikace programu primarni prevence uzivani navykovych latek]. Adiktologie, 6, 514-519.

Miovsky, M., Skacelova, L., Cablova, L., Vesela, M., \& Zapletalova, J. (2012). School-based prevention of risk behaviour: proposed structure, scope, and content of the Basic Preventive Programme [Navrh struktury, rozsahu a obsahu Minimálniho preventivniho programu prevence rizikového chováni pro základni školy]. Adiktologie, 12, 212-231.

MSMT $(2005,2008)$. Standards of Professional Qualifications of the Providers of Programmes of Primary Prevention of Substance Use. 
[Standardy odborné zpusobilosti poskytovatelu programu primarni prevence uzivani navykovych latek]. Praha: MŠMT.

Nevoralova, M., Pavlovska, A., \& Stastna, L. (2012). Evaluation of the school-based primary prevention of risk behaviour in the Czech Republic [Evaluace aktivit skolni primarni prevence rizikoveho chovani v Ceské republice]. Adiktologie, 12, 244-255.

Pavlas Martanová, V. (2012a). Development of the Standards and the certification process in primary prevention - an evaluation study [Vyvoj Standardu a procesu certifikace $v$ primarni prevenci evaluacni studie]. Adiktologie, 12, 174-188.

Pavlas Martanova, V. (2012b). Certification Rules and On-Site Inspection Guidelines for the Process of Certification According to the Professional Competency Standards of the Providers of Programmes of the Primary Prevention of Risk Behaviour. [Certifikcni rad a metodika mistniho setreni pro proces certifikace dle Standardu odborne zpusobilosti poskytovatelu programu skolske primarni prevence rizikoveho chovaní Praha: Univerzita Karlova v Praze \& Togga.

Pavlas Martanova, V., Behounkova, L., Exnerova, M., Charvat, M., Jurystova, L., Kaufova, T.... Stastna, L. (2012b). Standards of Professional Competency of the Providers of Programmes of the Primary Prevention of Risk Behaviour. [Standardy odborne zpusobilosti poskytovatelu programu skolske primarni prevence rizikoveho chovani]. Praha: Univerzita Karlova v Praze \& Togga.

Siruckova, M., Miovsky, M., Skacelova, L. (2012). School-based Prevention of Risk Behaviour: examples of good practice. [Priklady dobre praxe programu skolske prevence rizikoveho chovani]. Praha: Univerzita Karlova v Praze \& Togga. 